Ritrýnd grein birt 08. apríl 2021

\title{
Gildismat og sýn starfsfólks leikskóla á fullgildi í fölbreyttum barnahópi
}

\author{
Jóhanna Einarsdóttir og Eyrún María Rúnarsdóttir
}

Abstract Um höfunda About the authors Heimildir

Tengsl sem leikskólabörn mynda við önnur börn og kennara sína eru lykilatriði í námi peirra og vellíðan. Myndist góð tengsl skapast sú tilfinning að tilheyra í leikskólasamfélaginu. Hugtakið fullgildi vísar til pátttöku, félagslegra tengsla og peirrar tilfinningar að tilheyra. Rannsóknir sýna að börn af erlendum uppruna geta orðið utanveltu í jafningjahópi og að stuðningur starfsfólks getur skipt sköpum við að stuðla að fullgildi barna með erlendan bakgrunn. Markmið rannsóknarinnar sem hér er kynnt var að varpa ljósi á sýn og gildismat starfsfólks leikskóla á fullgildi í leikskólastarfi og valdastöðu barna með fjölbreyttan tungumála- og menningarbakgrunn í jafningjahópi. Jafnframt var skoðað hvort sýn starfsfólks var ólík eftir menntun pess og starfsreynslu. Gagna var aflað með rafrænum spurningalista sem starfsmenn 143 leikskóla af öllu landinu svöruðu. Um helmingur svarenda var leikskólakennarar og/eða með BA-gráðu, fjórðungur hafði lokið meistaragráðu eða diplómanámi að loknu BA-námi og fjórðungur hafði framhaldsskólapróf eða aðra menntun. Starfsfólkið stefndi almennt að pví að öll börn væru fullgildir pátttakendur í barnahópi, að pau væru viðurkennd „eins og pau eru“ og pað kaus að hafa foreldra með í ráðum um starfið. Greina mátti meiri trú á hæfni barna til að taka pátt í og stuðla að fullgildi meðal peirra sem höfðu leikskólakennaramenntun og/eða meistaragráðu og hinir síðarnefndu lögðu jafnframt meiri áherslu á samskipti og leik barna sem leið til fullgildis. Starfsfólkið varð helst vart við að tungumál gæti leitt til útilokunar sumra barna í jafningjahópi og hafði áhyggjur af stöðu barna með annan tungumála- og menningarbakgrunn. Vilji var til að stuðla að fullgildri pátttöku pessa hóps með auknum skilningi og umræðu um fjölbreytileika ásamt áherslu á vinatengsl.

Efnisorð: Fullgildi, gildismat starfsfólks leikskóla, börn með fjölbreyttan tungumála- og menningarbakgrunn, starfshættir leikskóla

\section{Inngangur}

Í gæðaviðmiðum Evrópuráðsins um leikskólamenntun er hlutverk leikskóla í mótun samfélagsins undirstrikað. Kveðið er skýrt á um að í fjölbreytilegu samfélagi leikskólans sé stuðlað að samstöðu, umburðarlyndi og jafnræði ásamt að réttindi barna séu sett í öndvegi (Evrópuráðið, 2019). Pessar áherslur eru samhljóða peirri stefnu sem birtist í Aðalnámskrá leikskóla 2011 par sem lýðræði, pátttaka, jafnrétti, samskipti og raddir barna eru lykilhugtök (Mennta- og menningarmálaráðuneytið, 2012). Kennarar gegna meginhlutverki í öllu skólastarfi og peirra er valdið pegar kemur að pví að túlka og útfæra námskrána. Gildi og gildismat starfsfólks leikskóla og sú sýn sem pað hefur á börn getur haft úrslitapýðingu fyrir velliððan og nám barna. 
Alpjóðavæðing, aukin fjölbreytni og flutningur fólks milli landa hefur mótandi áhrif á störf kennara. Íslenskt samfélag hefur próast og breyst á tiltölulega skömmum tíma, frá pví að vera fremur einsleitt yfir í fjölmenningarlegt samfélag. Leikskólinn er oft fyrsti viðkomustaður fjölskyldna sem flytjast til landsins og með hverju árinu sem líður fjölgar börnum í leikskólum landsins með fjölbreyttan menningar- og tungumálabakgrunn. Árið 2019 voru leikskólabörn með annað móðurmál en íslensku alls 2713 (14\%) en til samanburðar voru pau 1614 (9\%) árið 2009 (Hagstofa Íslands, 2020a). Á skömmum tíma eru leikskólar bví orðnir fjölmenningarlegur vettvangur og starfsfólk leikskóla hefur purft að laga starfið að fjölbreyttari barnahópi en áður. Í niðurstöðum TALIS-rannsóknarinnar kemur fram að íslenskir leikskólastjórar telja að starfsfólkið í leikskólum peirra álíti pað mikilvægt að börn geri sér grein fyrir að fólk frá öðrum löndum hafi önnur gildi en pau. Einnig kemur fram að peir telji mikilvægt að börn læri sem fyrst að bera virðingu fyrir annarri menningu (OECD, 2019).

Erlendar rannsóknir sýna að vellíðan barna í skóla hefur áhrif á námsárangur peirra. Tengsl nemenda við önnur börn og við kennara sína eru par mikilvægir áhrifapættir (Cerna, Andersson, Bannon og Borgonovi, 2019). Í pessari rannsókn er stuðst við hugtakið fullgildi sem er pýðing á enska orðinu belonging. Pað vísar til pátttöku og félagslegra tengsla og peirrar tilfinningar að tilheyra hópi barna í leikskóla. Með auknum fjölbreytileika í leikskólum landsins verður æ mikilvægara að auka pekkingu á hvernig unnið er með fullgildi barna í leikskólum. Hugtakið er í pessari rannsókn notað til að varpa ljósi á gildismat og hlutverk starfsfólks leikskóla og sýn pess á valdastöðu barna með fjölbreyttan tungumála- og menningarbakgrunn. Tilgangurinn er jafnframt að auka skilning á hvernig sú sýn endurspeglast í markmiðum peirra, starfsháttum og aðferðum sem miða að fullgildri pátttöku allra barna.

\section{Fræðilegur bakgrunnur}

Fullgildi er margslungið hugtak og hefur verið notað í ólíkum fræðigreinum á mismunandi hátt. Litið hefur verið á fullgildi sem pátt í pörf fólks til að finnast pað eiga heima, vera viðurkennt í hópi og pátttakendur í samfélagi (Stratigos, Bradley og Sumsion, 2014). Einnig hefur fullgildi verið talið til grundvallarparfa mannsins, sem frá unga aldri skapar tilfinningaleg tengsl við annað fólk, menningu, staði og hluti (Over, 2016).

Yuval-Davis (2006) hefur greint á milli annars vegar tilfinningalegs fullgildis (e. sense of belonging) og hins vegar pólitísks fullgildis (e. politics of belonging). Tilfinningalegt fullgildi vísar til tilfinningalegra tengsla við hópa, fólk eða staði par sem einstaklingnum finnst hann eiga heima, vera öruggur og tilheyra. Auk persónulegra tengsla felur tilfinningalegt fullgildi í sér félagslega vídd, p.e. að fólki finnst pað ekki eiga heima eða tilheyra ef pví er hafnað af peim sem eru par fyrir (Antonsich, 2010). Yuval-Davis lítur svo á að fullgildi snúist ekki aðeins um félagslega staðsetningu og tilfinningaleg tengsl heldur einnig pað hvernig pessir pættir eru metnir, p.e. pau gildi og pað gildismat sem fólk hefur. Samkvæmt Yuval-Davis felur pólitískt fullgildi í sér eignarhald og valdatengsl sem hafa áhrif á samskipti milli einstaklinga, hópa og umhverfis. Í huga Yuval-Davis snýst pólitískt fullgildi um pýðingu pess að vera pátttakandi og viðurkenndur í samfélagi og um pau landamæri sem aðgreina fólk og greina að „okkur“ og „pau“ (Antonsich, 2010; Yuval-Davis, 2006, 2011). May (2013) hefur einnig sýnt fram á að ekki er hægt að líta fram hjá félags- og menningarlegu samhengi pegar rætt er um fullgildi. Hún leggur áherslu á tengsl fullgildis einstaklinga við samfélagið og samfélagslegar breytingar.

Litið hefur veriðá leikskóla sem mikilvægan félags- og menningarlegan vettvang fyrir börn til að upplifa fullgildi (Dahlberg og Moss, 2005) og fullgildi sem mikilvægan pátt í nútímaleikskólamenntun, eins og endurspeglast m.a. í peim leikskólanámskrám sem helst er litið til, t.d. Te Whariki-námskránni á Nýja-Sjálandi (Ministry of Education New Zealand, 2017). Að undanförnu hafa fræðimenn rýnt með gagnrýnum hætti i hugtakið fullgildi og pýðingu pess fyrir menntun ungra barna. Stratigos, Bradley og Sumison (2014) hafa bent á að fullgildi geti einnig falið í sér aðskilnað og skapað landamæri sem stýri hegðun peirra sem eru fyrir innan og haldi um leið öðrum fyrir utan. Vakin hefur verið 
athygli á að fullgildi sumra barna geti haft í för með sér útilokun annarra og komið verst niður á börnum sem eru á einhvern hátt í viðkvæmri stöðu, t.d. peim börnum sem hafa annan tungumálaog menningarbakgrunn en meirihluti félaga peirra (Kernan, 2010). Petta á til dæmis við pegar góð tengsl hafa myndast milli barna sem hafa sterka stöðu í jafningjahópi og hafa hvorki pörf fyrir né sjá hag í að hleypa fleirum að. Press og samstarfsfólk fjalla um fullgildi í leikskólastarfi. Pau líta svo á að fullgildi vísi til samskipta og gagnkvæmra tengsla við fólk, staði og hluti. Jafnframt færa pau rök fyrir pví að fullgildi sé markmið sem ekki sé hægt að ná eingöngu innan leikskólans, heldur sé pað hád félagslegu samhengi og tengist hlutverki leikskólans í samfélaginu (Press, Woodrow, Logan og Mitchell, 2018).

Rannsóknir í íslenskum og erlendum leikskólum sýna að börn með erlendan bakgrunn eiga á hættu að vera jaðarsett og útilokuð í leikskólanum (Eyrún María Rúnarsdóttir og Svava Rán Valgeirsdóttir, 2019; Jóhanna Einarsdóttir og Sara M. Ólafsdóttir, 2020a, 2020b; Sadownik, 2018). Niðurstöður rannsóknar Sadownik (2018) með börnum pólskra innflytjenda í Noregi sýna að pað reyndist peim erfitt að hefja nám í norskum leikskólum af pví pau höfðu ekki pá kunnáttu og hæfni sem til var ætlast (t.d. tungumálið). Pess vegna áttu pau í erfiðleikum með að taka pátt í leik með öðrum börnum og pað hafði í för með sér að pau upplifðu sig utanveltu. Íslensk rannsókn leiddi í ljós að leikur og góð tengsl við önnur börn voru mikilvægir pættir fullgildis fyrir öll börn. Hins vegar kom í ljós að pau börn sem voru með erlendan bakgrunn léku sér frekar við börn sem einnig voru með erlendan bakgrunn og börn með íslenskan bakgrunn léku sér frekar við börn með innlendan bakgrunn. Niðurstöðurnar benda til töluverðs aðstöðumunar milli barna af erlendum uppruna og innfæddu barnanna. Börnin sem voru með erlendan bakgrunn höfðu minna val um leikfélaga og pátttöku í leik og pau voru frekar útilokuð af hinum börnunum (Jóhanna Einarsdóttir og Sara M. Ólafsdóttir, 2020b).

Kennarar gegna lykilhlutverki í að skapa skilyrði fyrir fullgildi í leikskólum. Hvernig litið er á og unnið er með fullgildi í leikskólastarfi veltur að verulegu leyti á gildum og gildismati starfsfólksins. Einnig veltur pað á peim gildum sem liggja að baki stefnumótun í menntakerfinu og endurspeglast m.a. annars í stefnu um menntun án aðgreiningar, fjölmenningarstefnu einstakra sveitarfélaga og aðalnámskrá leikskóla. Niðurstöður rannsóknar á fullgildi í finnskum leikskólum leiddu í ljós að pó að opinber stefnumótun mótaði leikskólastarfið, pá væri valdið að miklu leyti í höndum fagfólksins í leikskólanum. Aðalnámskrá veitir kennurum vald til að skipuleggja leikskólastarfið, hrinda pví í framkvæmd og meta pað. Рað eru líka kennararnir sem gefa foreldrum leyfi til að taka pátt. Vald er einnig í höndum barnanna, sem oft streitast á móti og reyna að komast hjá pví að fylgja reglum hinna fullorðnu. Sum börn hafa háa stöðu meðal barnanna og virðast hafa vald til að velja (e. involve) og til að útiloka. Niðurstöðurnar sýna spennu á milli samfellu og breytinga, einsleitni og fjölbreytileika, valds og áhrifa, minnihluta og meirihluta, og hún hefur áhrif á fullgildi barna í leikskólanum (Puroila, Juutinen, Viljamaa, Kyrönlampi og Takala, 2021).

Purdue og félagar (2009) benda á að í fjölmenningarlegum samfélögum sé ætlast til pess að kennarar beri virðingu fyrir börnum og fjölskyldum með ólíkan bakgrunn og ólík gildi. Pau benda á að pað geti verið áskorun fyrir kennara að líta með gagnrýnum huga á eigin gildi og starfshætti sem tengjast fjölbreytni og ígrunda hvort peir sjálfir eru hluti af vandamálinu eða hluti af lausninni. Pó að margar rannsóknir meðal kennara bendi til jákvæðra viðhorfa gagnvart fjölmenningu og fullgildri pátttöku hefur verið bent á að pað sé oft meira í orði en á borði. Kennarar viti pannig til hvers er ætlast af peim en pegar kemur að starfsháttum peirra sjálfra geti raunin verið önnur (Phillips, 2010; Puroila, Emilson, Pálmadóttir, Piskur og Tofteland, í prentun). Niðurstöður rannsóknar á fullgildi meðal íslenskra leikskólakennara sýna töluverðan mun á orðum og athöfnum. Aðspurðir lögðu kennararnir áherslu á mikilvægi pess að öllum börnunum fyndist pau tilheyra barnahópnum og sögðust leitast við að efla vináttutengsl og pátttöku ólíkra barna í leikskólanum. Pessar hugmyndir virtust pó ekki endurspeglast nema að litlu leyti í starfsháttum peirra, par sem börnin voru mjög sjálfbjarga í daglegum athöfnum og starfsfólkið skipti sér lítið af peim (Jóhanna Einarsdóttir og Sara M. Ólafsdóttir, 2020b). 
Rannsókn á fullgildi barna í finnskum leikskólum sýndi að fullgildi tengdist gildum og gildismati starfsfólksins. Í ljós kom spenna á milli fullgildis barna og útilokunar, á milli stöðugleika og óstöðugleika, sem og milli áherslu á einstaklinginn annars vegar og hópinn hins vegar. Niðurstöðurnar sýndu að fullgildi fól í sér hvoru tveggja félagslega pátttöku og pá tilfinningu að tilheyra hópi, en einnig félagslega og tilfinningalega útilokun sem próaðist í daglegum samskiptum. Í ljós kom að útilokun barna átti sér í auknum mæli stað pegar starfsfólkið var ekki nærri (Juutinen, 2018; Juutinen, Puroila og Johansson, 2018).

Niðurstöður rannsóknar á fullgildi meðal kennara ungra barna í fimm löndum, m.a. á Íslandi, sýna að fullgildi felur í peirra huga í sér flokkun, tilfinningar og gildismat. Með flokkun er átt við flokkun fólks í ákveðna hópa. Til dæmis litu kennararnir svo á að börn með erlendan bakgrunn væru í sérstökum hópi pví pau væru frábrugðin öðrum. Í hugum peirra tengdust tilfinningar einnig fullgildi. Pannig var fullgildi barna tengt nálægð, samveru og pátttöku. Félagsleg tengsl og félagsleg virkni voru talin eftirsóknarverðari en einvera og ómannblendni. Gildi og gildismat kennaranna réð einnig miklu um hvernig peir litu á fullgildi. Lýðræðisleg gildi sem snerta fjölbreytileika, pátttöku allra barna og jafnrétti voru talin eftirsóknarverð (Puroila o.fl., í prentun). Tillett og Wong (2018) komust einnig að pví að skilningur leikskólakennara á fullgildi var oftast tengdur tilfinningum, p.e. góðum tengslum, stuðningi og öryggi. Kennurunum í rannsókn peirra fannst félagslegt fullgildi einnig mikilvægt og töluðu um mikilvægi pess að börnum fyndist pau falla inn í og vera hluti af hópnum. Höfundar benda á að fullgildi og útilokun endurspegli pólitíska sýn og að skilningur leikskólakennara á fullgildi móti starf peirra með börnunum.

Rannsóknir sýna að stuðningur starfsfólks getur skipt sköpum pegar kemur að pví að skapa aðstæður fyrir fullgildi barna með erlendan bakgrunn (Arvola, Lastikka og Reunamo, 2017; Juutinen, 2018; Kultti, Pramling og Pramling Samuelsson, 2017). Leikskólakennarar hafa pví mikilvægu hlutverki að gegna í að styðja vináttu ólíkra barna og aðstoða pau við að próa vináttutengsl. Með pví að skapa aðstæður í leik par sem styrkleikar barna með ólíkan bakgrunn geta notið sín og sameiginleg reynsla skapast geta kennarar stuðlað að fullgildi. Sé pessi stuðningur ekki fyrir hendi eykst hætta á að börn með erlendan bakgrunn verði frekar útilokuð (Wang, Palonen, Hurme og Kinos, 2019; Zachrisen, 2018). Kalkman og Clark (2017) skoðuðu hlutverk leikskólakennara í leik barna og sáu að börn með erlendan bakgrunn höfðu ekki pá menningarbundnu pekkingu sem purfti til að taka pátt í leik með félögum sínum. Hlutverkaleikurinn var eins konar menningarhandrit (e. cultural script) sem börnin notuðu til að kanna og láta reyna á menningarlandamærin í barnahópnum. Pví var hlutverk starfsfólksins í að skapa félagslegt rými og tækifæri afar mikilvægt. Nutbrown og Clough (2009) hafa vakið athygli á að ef kennarar hafa skilning á sjónarmiðum barna um fjölbreytni geta peir notað kennsluaðferðir sem draga úr staðalímyndum og fordómum. Rannsókn peirra sýndi að fullgildi í leikskólum veltur á starfsfólki sem sér til pess að börn séu sátt við sjálf sig, hafi jákvætt viðhorf til fjölbreytileika í barnahópnum og séu örugg með stöðu sína í leikskólasamfélaginu.

\section{Markmið og rannsóknarspurningar}

Leikskólakennarar og leiðbeinendur í leikskólum gegna lykilhlutverki í að stuðla að og styðja börn til fullgildis og pær leiðir sem starfsfólk fer tengjast gildum pess og gildismati. Markmið rannsóknarinnar sem hér er kynnt var að varpa ljósi á sýn og gildismat starfsfólks leikskóla á fullgilda pátttöku allra barna í leikskólastarfi og valdastöðu barna með fjölbreyttan tungumála- og menningarbakgrunn í jafningjahópi. Jafnframt var skoðað hvort sýn starfsfólks var ólík eftir menntun pess og starfsreynslu. Tilgangurinn er að auka skilning á hvernig sú sýn endurspeglast í markmiðum peirra, starfsháttum og aðferðum sem miða að fullgildri pátttöku allra barna. 
Rannsóknarspurningar eru eftirfarandi:

1. Hver er sýn pátttakenda á markmið, starfshætti og aðferðir sem miða að fullgildri pátttöku allra barna?

2. Hver er sýn pátttakenda á valdastöðu barna með fjölbreyttan tungumála- og menningarbakgrunn í jafningjahópi?

3. Hvernig sjá pátttakendur sitt hlutverk í að styðja börn og fjölskyldur til fullgildrar pátttöku í leikskólanum?

4. Er munur á sýn og gildismati pátttakenda eftir menntun og starfsreynslu?

\section{Аðferð}

Rannsóknin er samstarfsverkefni rannsakenda í Finnlandi, á Íslandi, í Noregi, Svípjóð og Hollandi. Hún er hluti yfirgripsmikils Nordforsk-rannsóknarverkefnis sem ber heitið „Politics of belonging: Promoting children's inclusion in educational settings across borders“. Markmið með heildarverkefninu var að auka pekkingu á fullgildi barna í mismunandi menntastofnunum og pað beindist að tækifærum og takmörkunum barna til pátttöku í jafningjahópi, einkum barna með fjölbreyttan félagslegan og/eða menningarlegan bakgrunn. Beitt var eigindlegri og megindlegri aðferð við gagnasöfnun en pær niðurstöður sem kynntar eru hér byggjast á megindlegum hluta verkefnisins. Sá hluti fólst í hönnun staðlaðs spurningalista sem alpjóðlega teymið vann að á grunni fræðilegra kenninga um fullgildi (Yuval-Davis, 2006). Spurningalistinn var forprófaður og lagfærður í samræmi við ábendingar sem fram komu. Hér er fjallað um svör íslensks leikskólastarfsfólks.

\section{Pátttakendur}

Upplýsingar um rannsóknina og slóð á spurningalista á netinu voru sendar á netföng leikskólastjóra eða yfirmanna leikskólamála sveitarfélaga á landinu öllu og voru peir beðnir að áframsenda til starfsfólks leikskólanna. Sömu hentugleikaaðferð var beitt í öllum aðildarlöndum rannsóknarinnar í pví skyni að ná til sem flestra og fá nægilegan fjölda svara pannig að innsýn fengist í nýtt viðfangsefni. Svarhlutfall netkannana er oft lágt og hefur farið lækkandi síðustu ár. Meðal ástæðna pess er aukinn fjöldi kannana sem dregur úr áhuga á að svara, tölvupóstur kemst ekki til skila, viðtakendur sjá ekki ávinning af að taka pátt eða treysta pví ekki að öryggis sé gætt við vörslu upplýsinga (Evans og Mathur, 2018). Í pessari könnun bárust svör frá 143 starfsmönnum. Par á meðal voru 36 (25\%) leikskólakennarar, 25 (18\%) höfðu lokið framhaldsnámi, svo sem meistaragráðu, 35 (25\%) voru með BA-gráðu, 10 (7\%) höfðu lokið diplómanámi eftir BA-gráðu og 11 (8\%) höfðu lokið framhaldsskóla. Pátttakendur endurspegluðu starfsmannahóp leikskóla að pví leyti að peir höfðu fjölbreyttan menntunarbakgrunn en hærra hlutfall pátttakenda í könnuninni hafði háskólamenntun sé miðað við tölur um starfsfólk leikskóla frá Hagstofu Íslands (2020b) og lægra hlutfall framhaldsskólamenntun. Petta ber að hafa í huga við túlkun niðurstaðna. Alls merktu 26 (17\%) við möguleikann annað eða svöruðu ekki spurningunni. Spurningu um starfsaldur svöruðu 142 og höfðu 33 (23\%) starfað í fimm ár eða skemur í leikskólanum, 13 (9\%) höfðu starfað í 6-10 ár, 19 (13\%) í 11-15 ár, 19 (13\%) í 16-20 ár og 58 (41\%) höfðu starfað í leikskóla lengur en 20 ár.

\section{Mælitæki}

Til að svara fyrstu rannsóknarspurningu var unnið úr fimm spurningum spurningalistans sem lutu að mati leikskólakennara og leiðbeinenda á mikilvægi ákveðinna markmiða, aðferða eða hugmynda um menntun pegar unnið væri að fullgildi í leikskólanum. Í öllum fimm spurningunum voru nokkrar fullyrðingar sem sneru að starfi peirra og voru pátttakendur beðnir að raða peim eftir mikilvægi. Pátttakendur voru ekki bundnir af pví að gefa hverri fullyrðingu eigið sæti í röðinni og gátu til að mynda sett fleiri en eina fullyrðingu sem sitt mikilvægasta val. Spurt var um markmið pegar börn væru studd til fullgildis og gefnir sex möguleikar sem pátttakendur voru beðnir að raða 
eftir mikilvægi ( 1 = mikilvægast til 6 = léttvægast). Dæmi um möguleika voru: 1$)$ að öll börnin séu fullgildir pátttakendur í barnahópnum, 2) öll börnin séu í vináttusambandi við að minnsta kosti eitt annað barn, 3) öll börnin séu viðurkennd „eins og pau eru“.

Í annarri spurningu voru fjórir möguleikar um markmið pegar starfsfólk styddi börn til fullgildis og voru pátttakendur beðnir að raða peim eftir mikilvægi. Dæmi um svarmöguleika voru: 1) að öðlast skilning á fjölbreytileika, 2) að skilja og ræða eigin tilfinningar og annarra um fjölbreytileika. Næstu tvær spurningar beindust að mikilvægum hugmyndum um menntun pegar börn væru studd til fullgildis. Í báðum spurningum voru pátttakendur beðnir að velja annan möguleika af tveimur. Annars vegar voru peir beðnir að velja á milli fullyrðinganna: 1) sem leikskólakennari/leiðbeinandi legg ég aðallega áherslu á parfir alls barnahópsins, 2) sem leikskólakennari/leiðbeinandi legg ég aðallega áherslu á parfir hvers einstaks barns. Hins vegar voru pátttakendur beðnir að velja á milli fullyrðinganna: 1) sem leikskólakennari/leiðbeinandi legg ég aðallega áherslu á að börn læri um fullgildi í gegnum samskipti og leik með öðrum, 2) sem leikskólakennari/leiðbeinandi legg ég áherslu á að vera fyrirmynd svo börnin læri um fullgildi. Pá var spurt um starfshætti í fjölbreyttum barnahópi. Pátttakendur voru beðnir að raða átta atriðum eftir mikilvægi og voru dæmi um svarmöguleika: 1) að vera fyrirmynd í að bjóða öðrum að vera með, 2) að hvetja börnin til pess að hlusta á sjónarmið annarra og 3) að styðja börnin til pess að vinna saman að lausn vandamála sem tengjast pví að vera fullgildur pátttakandi eða vera útilokaður í leikskólanum. Til að auðvelda greiningu á markmiðum, hugmyndum og kennsluaðferðum eftir menntun og starfsaldri og í tengslum við sýn pátttakenda á fullgildi voru svörin flokkuð í tvennt fyrir hverja spurningu. Í fyrri flokknum voru pau atriði sem póttu mikilvægust eða frekar mikilvæg (gildi 1 og 2) og í peim síðari atriði sem póttu síður mikilvæg (samanlögð önnur atriði).

Rannsóknarspurningu um sýn pátttakenda á valdastöðu barna með fjölbreyttan tungumála- og menningarbakgrunn var svarað með tveimur spurningum úr spurningalista. Pátttakendur voru beðnir að meta hvort sum börn á deildinni útilokuðu önnur börn vegna menningarlegs bakgrunns, tungumáls, fötlunar, félagslegrar stöðu, trúarlegs bakgrunns eða einhvers annars. Svarmöguleikar voru sjö, allt frá 1 = aldrei til 7 = alltaf fyrir hvert framangreindra atriða. Til einföldunar var svarmöguleikum fækkað í fjóra (aldrei, sjaldan, stundum, oft) með pví að leggja saman svör ( 2 og $3=$ sjaldan og 5 og 6 =oft). Enginn pátttakandi merkti við svarmöguleikann 7 = alltaf. Í spurningu um hæfni og möguleika barna til fullgildis í jafningjahópnum voru átta fullyrðingar, til dæmis: „Börn geta ekki skapað sína eigin jafningjahópa án stuðnings kennara“, „Börn eru fær um að taka pátt í að próa reglur um fullgilda pátttöku í hópi barna með fjölbreyttan bakgrunn“ og „Börn sem purfa sérstakan stuðning eiga í erfiðleikum með að vera hluti af jafningjahópnum“. Svarmöguleikar voru sjö, allt frá $1=$ mjög ósammála til $7=$ mjög sammála. Til einföldunar var svarmöguleikum fækkað í fimm með pví að leggja saman svör fyrir gildin 2 og 3 og fyrir 5 og 6 . Áreiðanleikapróf Cronbach's alpha var 0,86 fyrir mælinguna.

Spurningu um sýn pátttakenda á hlutverk sitt við að styðja börn og fjölskyldur til fullgildis var svarað með sjö fullyrðingum sem pátttakendur voru beðnir að taka afstöðu til. Dæmi um spurningar voru: „Öllum foreldrum finnst peir vera fullgildir í leikskólanum mínum“ og „Рað er mikilvægt að hafa foreldra með í ráðum pegar barn peirra útilokar aðra vegna ólíkrar hæfni peirra eða bakgrunns“. Svarmöguleikar voru sjö, allt frá $1=$ mjög ósammála til 7 = mjög sammála. Líkt og í fyrrgreindri spurningu var svarmöguleikum fækkað í fimm til einföldunar.

Að lokum beindist rannsóknin að peirri spurningu hvort sýn pátttakenda væri mismunandi eftir menntunarbakgrunni peirra og starfsreynslu. Spurt var hvaða menntun viðkomandi hefði lokið og voru svarmöguleikar eftirfarandi: Framhaldsnám (t.d. meistaranám), leikskólakennari, diplóma (að loknu grunnháskólanámi, t.d. B.Ed.), BA-gráða, leikskólaliði eða annað. Miðað var við mestu menntun pegar spurningin var notuð við greiningu. Pátttakendur voru beðnir að skrá hversu mörg ár peir höfðu starfað við kennslu og voru svörin flokkuð í fimm flokka. Í peim fyrsta voru kennarar og leiðbeinendur sem höfðu starfað í fimm ár eða skemur við kennslu, pá peir sem höfðu starfað í sex til 10 ár, par næst peir sem höfðu starfað í 11 til 15 ár, pá peir sem höfðu starfað í 16 til 20 ár og loks peir sem höfðu starfað í 20 ár eða lengur við kennslu. 


\section{Framkvæmd og gagnagreining}

Spurningalistinn var hannaður af alpjóðlega teyminu og pýddur á íslensku. Íslenska pýðingin var yfirfarin af teymi íslenskra rannsakenda, listinn prófarkalesinn og að pví búnu bakpýddur á ensku. Bakpýðingin var yfirfarin með íslenskufræðingi og breytingar gerðar par sem purfti. Spurningalistinn var í kjölfarið forprófaður af tveimur leikskólakennurum og í framhaldi af pví var haldinn fundur með peim til að ræða spurningarnar. Рað tók um 15 mínútur að svara listanum og við prófun kom fram að skýra mætti orðalag í nokkrum tilfellum til að auðvelda pátttakendum að svara spurningum. Aflað var leyfis fyrir rannsókninni hjá skólaskrifstofum og deildum sveitarfélaga og hjá leikskólastjórum. Í sumum tilfellum fengust netföng leikskólastjórnenda uppgefin og var pá haft beint samband við pá og falast eftir pátttöku. Í öðrum tilfellum var haft samband við fulltrúa sveitarfélaga sem dreifðu upplýsingum og slóð á spurningalista til leikskólastjóra. Leikskólastjórnendur voru beðnir að dreifa listanum til starfsmanna. Sendar voru ítrekanir með ósk um svörun á netföng tengiliða.

Spurningalistinn var vistaður í forritinu Key Survey á vegum Queensland University of Technology en forritið er hannað í peim tilgangi að koma til móts við siðferðileg og tæknileg viðmið um spurningalistakannanir. Nafnleynd pátttakenda og sveitarfélaga var tryggð. Tekið var skýrt fram að pátttaka væri frjáls, pátttakendur gætu hætt pátttöku hvenær sem væri og sleppt einstökum spurningum. Einungis rannsakendur sem taka pátt í verkefninu hafa aðgang að gögnum, sem eru geymd á öruggum stað og verður eytt 31.12.2035. Pátttakendur gátu valið um hvort peir notuðu ensku eða íslensku útgáfuna af spurningalistanum. Áströlsku rannsakendurnir sáu um að opna og loka könnuninni.

Greining gagna fór fram með SPSS-forritinu. Svör leikskólakennara og leiðbeinenda við spurningum um mikilvæg markmið, hugmyndir og kennsluaðferðir og um sýn á hæfni barna og samstarf við foreldra voru reiknuð sem hlutföll og eru sýnd myndrænt. Pá var kannað með kí-kvaðrat-prófi hvort munur væri á milli hópa sem höfðu mismunandi menntun eða starfsaldur að baki. Jafnframt var kíkvaðrat-próf notað til að meta hvort munur væri á sýn pátttakenda á hæfni og möguleika barna eftir peim áherslum sem peir höfðu í starfi sínu.

\section{Niðurstöður}

Fjallað er um niðurstöður rannsóknarinnar í tveimur köflum. Í fyrri kaflanum er leitast við að varpa ljósi á gildismat og sýn pátttakenda á hlutverk sitt í að styðja börnin til fullgildrar pátttöku. Sjónum er beint að markmiðum og starfsháttum pátttakenda og pau tengd sýn peirra á hæfni og möguleika barna til fullgildrar pátttöku í leikskólanum. Sỉðari kaflinn fjallar um sýn leikskólakennara og leiðbeinenda á fullgilda pátttöku og útilokun bæði barna og foreldra í leikskólastarfinu.

\section{Markmið og starfshættir pegar unnið er að fullgildi}

Í umfjöllun um markmið leikskólakennara og leiðbeinenda var annars vegar spurt um mikilvæg markmið pegar börn eru studd til fullgildis og hins vegar um mikilvæg markmið pegar fjallað er um fjölbreytileika í leikskólastarfinu. Mynd 1 sýnir hvernig pátttakendur mátu mikilvægi sex markmiða pegar peir styddu börnin til fullgildis. 


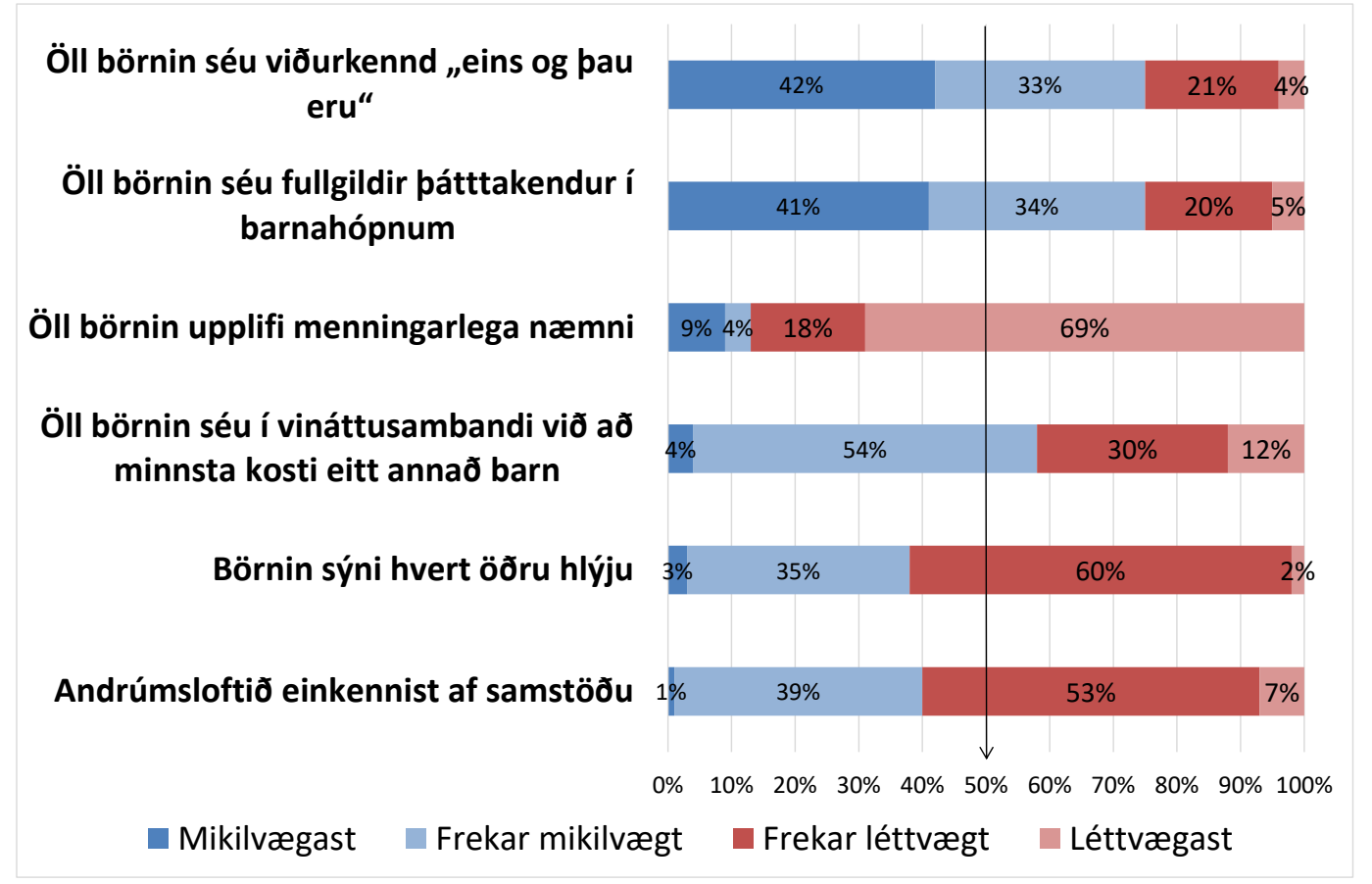

Mynd 1. Mikilvægi markmiða pegar leikskólakennarar og leiðbeinendur styðja börn til fullgildis.

Sjá má að tvö atriði póttu oftast mikilvægust eða frekar mikilvæg. Pau voru annars vegar að öll börn væru viðurkennd eins og pau eru (75\%) og hins vegar að öll börn væru fullgildir pátttakendur í barnahópnum (75\%). Í báðum tilfellum fannst yfir 40\% starfsfólks pessi markmið mikilvægust. Petta segir pó ekki alla söguna pví pegar litið er til pess hvað pótti frekar mikilvægt kemur fram að 58\% fannst frekar mikilvægt eða mikilvægast að öll börn væru í vinasambandi við að minnsta kosti eitt annað barn. Ekki reyndist vera munur eftir menntun eða starfsaldri starfsfólks við mat á mikilvægi markmiða. Við nánari greiningu komu fram marktæk tengsl markmiðsins að öll börn væru í vinasambandi við að minnsta kosti eitt annað barn og pess að börn gætu tjáð sig og boðið öðrum að vera fullgildir pátttakendur, kí-kvaðrat: $X^{2}(6, \mathrm{~N}=133)=14,8, p=0,022$. Með öðrum orðum fór pað saman í huga starfsfólks að mikilvægt væri að börnin eignuðust vini í leikskólanum og trú peirra á hæfni og virkni barna við að stuðla að pátttöku og fullgildi allra barna. Einnig voru tengsl á milli pess að leggja áherslu á markmiðið að öll börn séu fullgildir pátttakendur í barnahópnum og pess að líta svo á að börn með annað móðurmál en íslensku eigi í erfiðleikum með að taka pátt í samskiptum við jafningja, $X^{2}(4, \mathrm{~N}=138)=10,0, p=0,040$. Pessi tengsl komu fram í að færri peirra sem lögðu áherslu á markmið um fullgildi allra barna fannst börn með annað móðurmál eiga í vanda með jafningjasamskipti. 


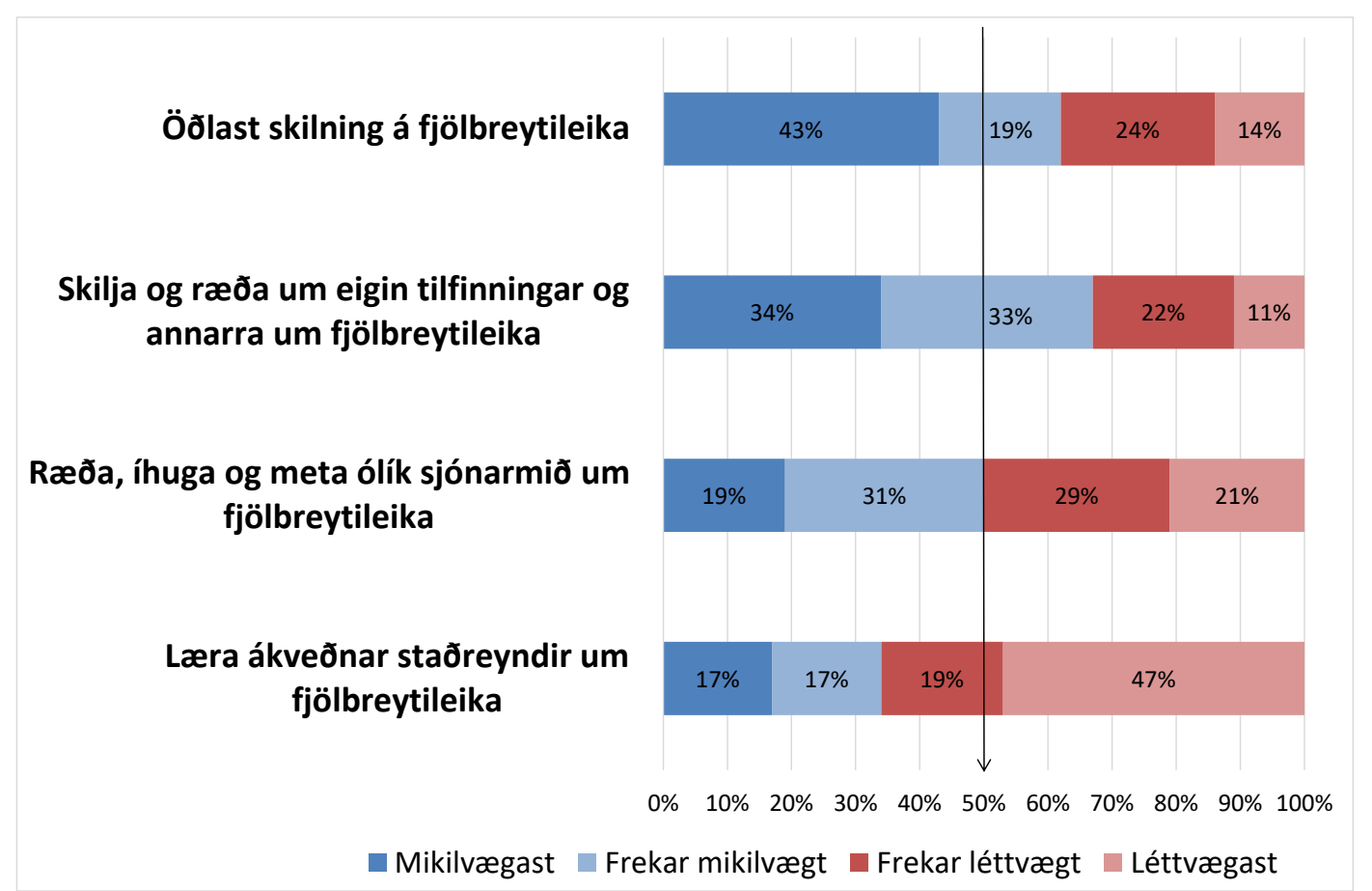

Mynd 2. Mikilvægi markmiða pegar leikskólakennarar og leiðbeinendur fjalla um fjölbreytileika.

Mynd 2 sýnir pau markmið sem leikskólakennurum og leiðbeinendum pótti mikilvægt að stefna að í sambandi við fjölbreytileika í leikskólastarfinu. Ríflega 40\% fannst mikilvægast að börn öðluðust skilning á fjölbreytileika og 31\% fannst mikilvægast að börn gætu skilið og rætt eigin tilfinningar og annarra um fjölbreytileika. Heldur hærra hlutfalli peirra sem höfðu leikskólakennaramenntun eða diplóma að lokinni BA-gráðu fannst petta mikilvægast eða mjög mikilvægt (um 70\%) en peirra sem höfðu aðra menntun (56-63\%) en munurinn var ekki tölfræðilega marktækur. Pegar litið var til pess hvað pótti frekar mikilvægt voru framangreind markmið ofarlega í huga pátttakenda en að auki fannst 31\% frekar mikilvægt að ræða, íhuga og meta ólík sjónarmið um fjölbreytileika. Peir sem lögðu áherslu á að börn öðluðust skilning á fjölbreytileika höfðu tilhneigingu til að telja börn með annað móðurmál en íslensku eiga í erfiðleikum með að taka pátt í samskiptum við jafningja samkvæmt marktektarprófinu kí-kvaðrat, $X^{2}(4, \mathrm{~N}=136)=9,5, p=0,049$. 


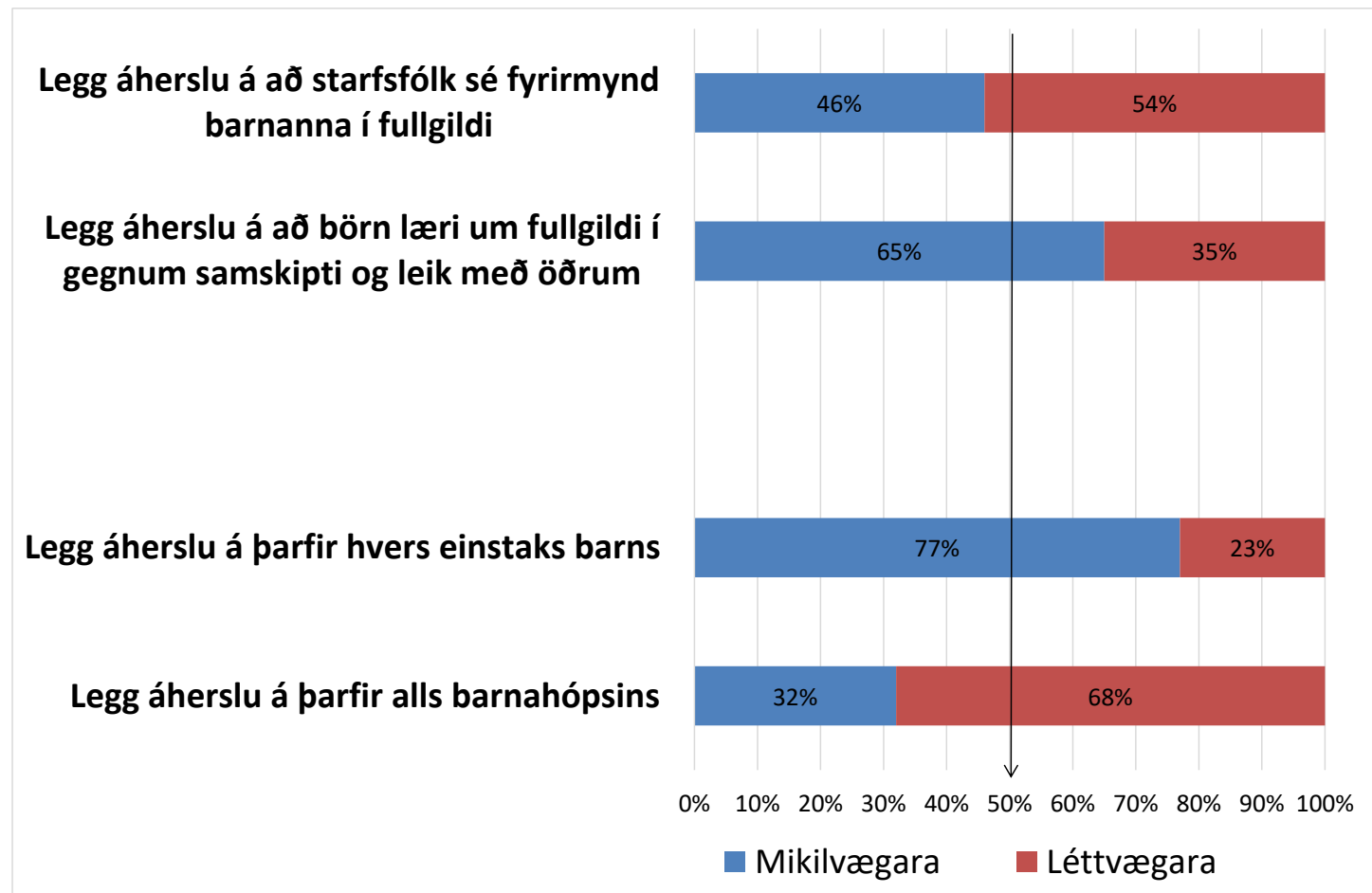

Mynd 3. Áherslur leikskólakennara og leiðbeinenda pegar peir styðja börn til fullgildis í leikskólanum.

Pegar pátttakendur voru beðnir að velja á milli pess hvort peir legðu áherslu á að börn lærðu um fullgildi í gegnum samskipti og leik með öðrum eða með pví að vera sjálfir fyrirmynd barnanna völdu 65\% hið fyrrnefnda, eins og fram kemur á Mynd 3. Peir sem lögðu áherslu á fullgildi í gegnum samskipti og leik voru líklegri til að finnast börn fær um að skilja sjónarmið barna með mismunandi hæfni eða bakgrunn og reyndust pau tengsl marktæk, $X^{2}(4, \mathrm{~N}=133)=11,3, p=0,024$. Pá fundust tengsl á milli pess að leggja áherslu á að starfsfólk væri fyrirmynd og pess að finnast börn sem purfa sérstakan stuðning eiga erfitt með að tilheyra jafningjahópnum, $X^{2}(4, \mathrm{~N}=114)=10,3, p=0,035$.

Pegar kannað var hvort svörin væru mismunandi eftir menntun eða starfsaldri fannst ekki marktækur munur. Pó mátti sjá að heldur hærra hlutfall peirra sem höfðu meistaragráðu lagði áherslu á að börn lærðu um fullgildi í gegnum leik, eða 72\%, en hlutfallið var 57\% til 67\% hjá öðrum hópum. Einnig kom í ljós að heldur hærra hlutfall peirra sem höfðu starfað stuttan tíma í leikskólanum sagðist leggja áherslu á petta, eða 77\% peirra sem höfðu starfað par í allt að 10 ár. Hlutfallið var lægra í öðrum starfsaldurshópum en hér verður að setja fyrirvara vegna pess hve fáir voru í hverjum hópi.

Pátttakendur voru einnig beðnir að velja á milli pess hvort peir legðu áherslu á parfir alls barnahópsins eða parfir hvers einstaks barns pegar peir stuðluðu að fullgildi í leikskólanum og eru pau svör einnig sýnd á Mynd 3. Fram kom að 77\% lögðu áherslu á parfir hvers einstaks barns og 23\% á parfir alls barnahópsins. Pegar litið var til menntunar kom í ljós að pessi áhersla pótti mikilvægust hjá yfir 70\% allra pátttakenda en pó lögðu leikskólakennarar öðrum fremur áherslu á parfir hvers einstaks barns, eða um 83\%. Pegar starfsaldur var skoðaður kom í ljós að pví lengur sem pátttakendur höfðu starfað í leikskóla, peim mun líklegri voru peir til að velja petta markmið og var sú niðurstaða marktæk, $X^{2}$ $(4, \mathrm{~N}=134)=11,0, p=0,026$. Meðal peirra sem höfðu starfað í 20 ár eða lengur í leikskóla sögðust 88\% leggja áherslu á parfir hvers einstaks barns á móti $57 \%$ peirra sem höfðu starfað í fimm ár eða skemur.

Pátttakendur voru spurðir hvaða starfshætti peir kysu pegar peir ynnu með fjölbreyttum barnahópi. Mynd 4 sýnir svörin og skal minnt hér á að sumir pátttakendur settu fleiri en eitt atriði í fyrsta sæti sem mikilvægustu aðferðina. 


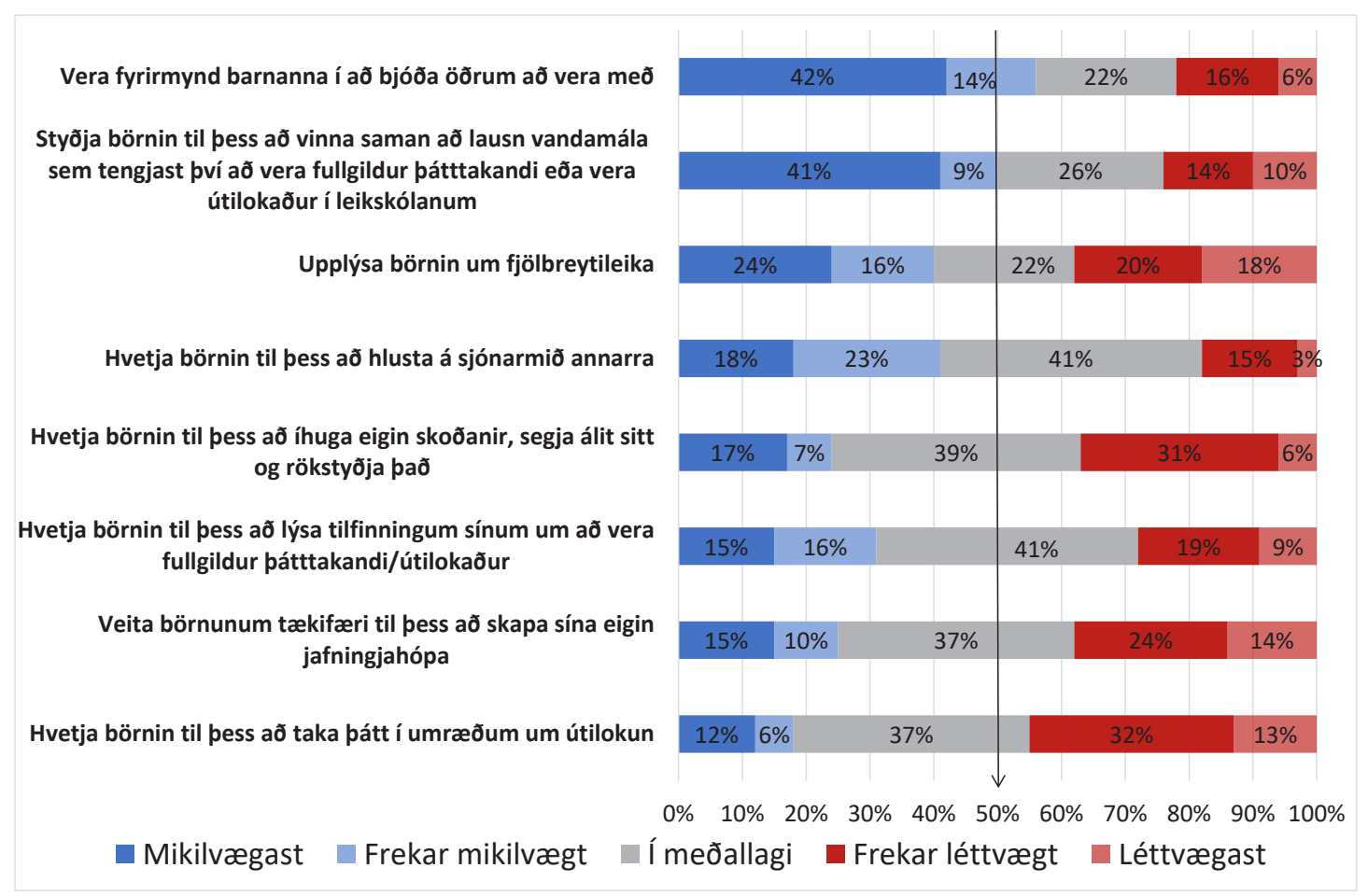

Mynd 4. Starfshættir í fjölbreyttum barnahópi.

Mikilvægast pótti að vera fyrirmynd barnanna í að bjóða öðrum að vera með (42\%) og að styðja börnin til pess að vinna saman að lausn vandamála sem tengjast pví að vera fullgildur pátttakandi eða vera útilokaður í leikskólanum (41\%). Um og yfir 50\% svara voru á pá leið að pessir tveir möguleikar væru annaðhvort mikilvægastir eða frekar mikilvægir. Pá fannst 40\% mikilvægast eða frekar mikilvægt að upplýsa börnin um fjölbreytileika. Tilhneiging var í pá átt að pví lengur sem pátttakendur höfðu starfað á leikskóla, peim mun hærra hlutfall valdi aðferðina að vera fyrirmynd barna í að bjóða öðrum að vera með. Pessa aðferð völdu 63\% peirra sem voru með yfir 20 ára starfsaldur og 59\% peirra sem voru með 16-20 ára starfsaldur, en 47\% peirra sem höfðu starfað skemur í leikskólanum. Tengslin voru pó ekki tölfræðilega marktæk.

Meðal annarra aðferða sem póttu mikilvægar var að hvetja börnin til pess að hlusta á sjónarmið annarra en alls pótti 41\% pað mikilvægast eða frekar mikilvægt. Prátt fyrir að áhersla á aðferðina væri ekki marktækt mismunandi eftir menntun vakti athygli að aðeins $27 \%$ starfsfólks með framhaldsskólamenntun völdu pessa aðferð sem mikilvægasta eða frekar mikilvæga en pað gerðu hins vegar 50\% starfsfólks með diplóma að lokinni BA-gráðu og 48\% peirra sem voru með meistarapróf.

Pegar kannað var hvort peir starfshættir sem póttu mikilvægir tengdust mati leikskólakennara og leiðbeinenda á hæfni og möguleikum barna til að hafa áhrif á fullgildi í leikskólastarfinu fundust marktæk tengsl nokkurra pátta. Pannig voru peir sem lögðu áherslu á að vera fyrirmynd barnanna í að bjóða öðrum að vera með líklegri til að finnast börn fær um að standa vörð um réttindi sín og annarra, $X^{2}(4, \mathrm{~N}=139)=12,0, p=0,017$. Einnig fundust tengsl milli pess að vilja styðja börnin til að vinna saman að lausn mála sem tengjast pátttöku eða útilokun og pess að vera ósammála peirri fullyrðingu að börn væru ófær um að skilja sjónarmið barna með annan bakgrunn eða hæfni en pau sjálf, $X^{2}(6, \mathrm{~N}=138)=15,1, p=0,029$. 


\section{Sýn pátttakenda á valdastöðu barna með fjölbreyttan tungumála- og menningarbakgrunn}

Í rannsókninni var sjónum beint að valdastöðu barna með annan tungumála- og menningarbakgrunn en íslenskan og hvernig peim gengi að fóta sig í barnahópnum. Pátttakendur voru beðnir að meta hvort og í hversu miklum mæli peir teldu leikskólabörn á deildinni par sem peir störfuðu verða fyrir útilokun af hálfu annarra barna. Spurt var hvort börnin sættu útilokun vegna fötlunar, trúar, tungumáls eða menningar. Mynd 5 sýnir svör pátttakenda við pessum spurningum.

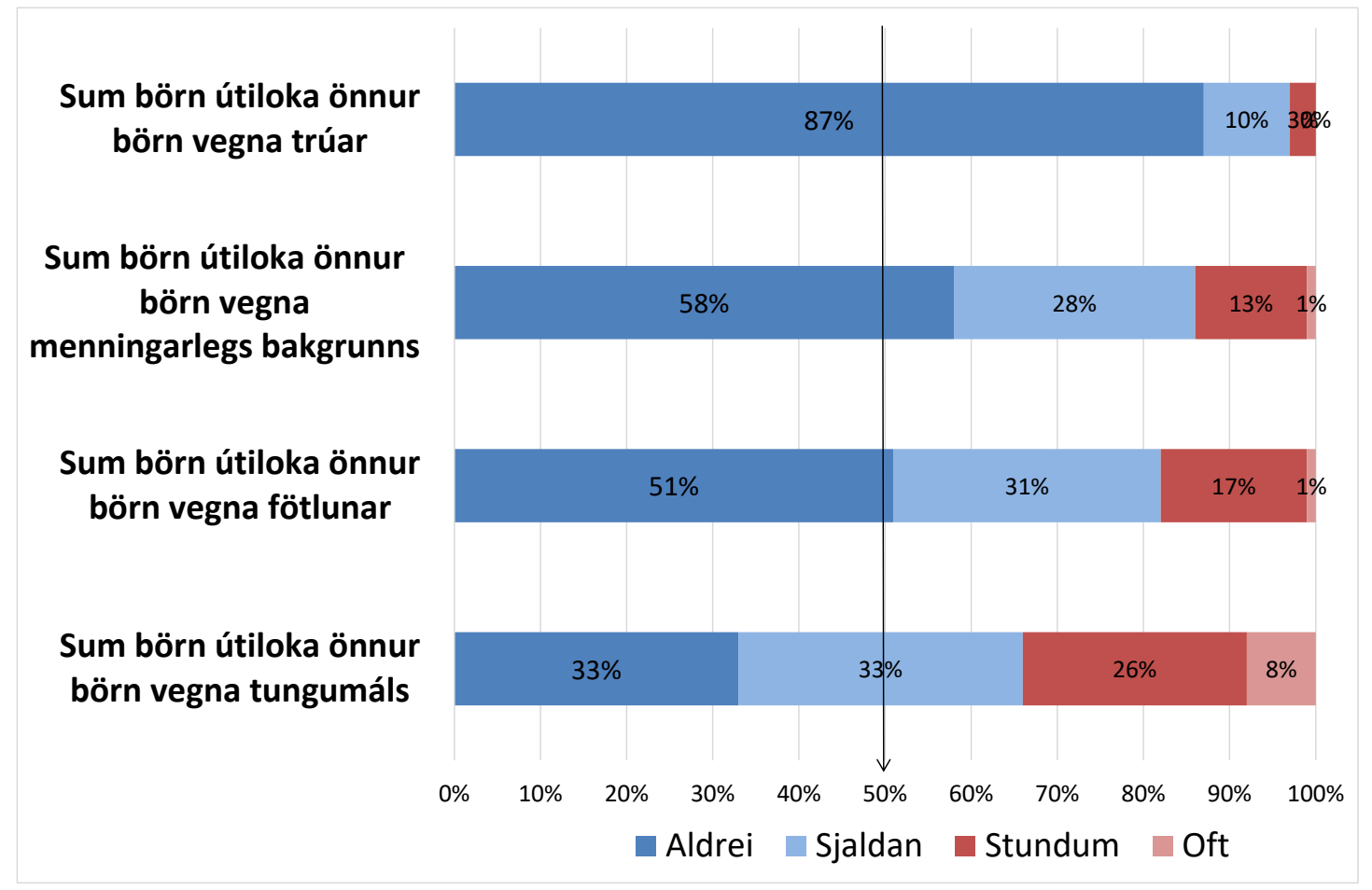

Mynd 5. Mat leikskólakennara og leiðbeinenda á algengi pess að börn útiloki önnur börn vegna fötlunar, trúar, tungumáls eða menningarlegs bakgrunns.

Рað var mat yfir 50\% pátttakenda að börnin á peirra deild útilokuðu aldrei önnur börn vegna fötlunar eða menningarlegs bakgrunns. Síst var talið að börn væru útilokuð vegna trúar en $87 \%$ töldu pað aldrei eiga við. Pegar litið var til tungumáls sögðust 33\% aldrei verða vör við útilokun en á móti urðu 34\% leikskólakennara og leiðbeinenda stundum eða oft vör við að sum börn útilokuðu önnur börn vegna tungumáls. Fötlun var ástæða sem $18 \%$ sögðu stundum eða oft vera tilefni pess að börn væru útilokuð.

Athygli verður nú beint að sjónarmiðum pátttakenda um hæfni barnanna og möguleika peirra við aðstæður par sem unnið er að fullgildri pátttöku í jafningjahópnum. Mynd 6 sýnir hversu sammála eða ósammála leikskólakennarar og leiðbeinendur eru fullyrðingum um fullgilda pátttöku barna. Pau svör veita nánari innsýn í mat leikskólakennara og leiðbeinenda á pví í hvers konar aðstæðum fullgild pátttaka verður áskorun fyrir börnin og hvenær peir telja að vel gangi innan jafningjahópa. 


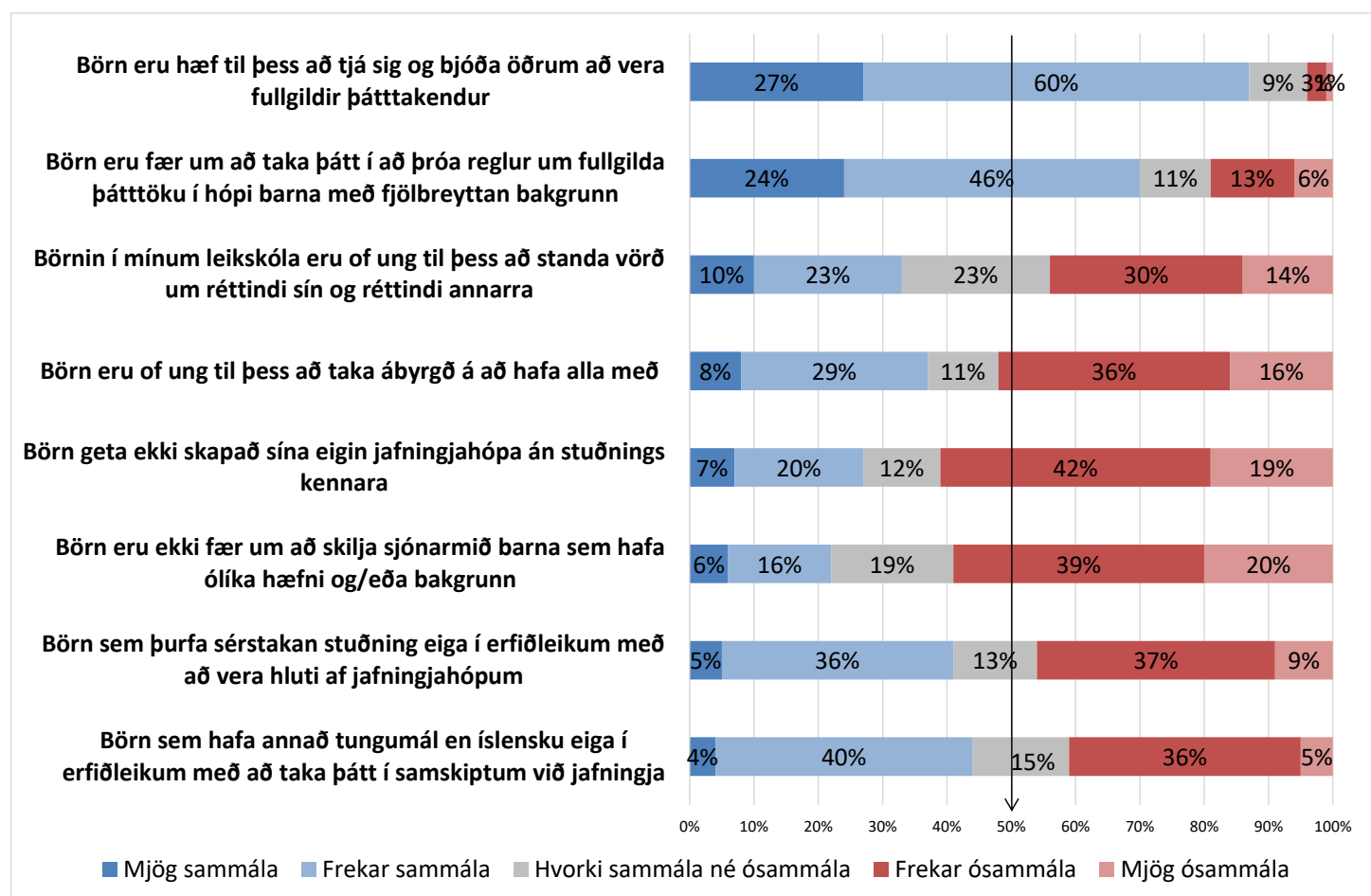

Mynd 6. Mat á hæfni og möguleikum barna til fullgildrar pátttöku í jafningjahópi.

Í takt við niðurstöðu um að tungumál gæti verið orsök útilokunar sumra barna voru 44\% pátttakenda sammála eða frekar sammála peirri fullyrðingu að börn með annað móðurmál en íslensku ættu í erfiðleikum í samskiptum við jafningja. Örlítið minni hópur, eða 41\%, var pessu mjög eða frekar ósammála. Svipaða sögu var að segja um börn sem purftu sérstakan stuðning. Pannig var $41 \%$ mjög eða frekar sammála pví að pessi hópur barna ætti í erfiðleikum með að vera hluti af jafningjahópi en $46 \%$ voru pessu mjög eða frekar ósammála.

Viðhorf leikskólakennara og leiðbeinenda til hæfni barna í að próa reglur um fullgildi eða bjóða öðrum að vera með voru jákvæð. Alls voru $70 \%$ mjög eða frekar sammála pví að börn gætu próað reglur um fullgilda pátttöku barna með fjölbreyttan bakgrunn og $87 \%$ pví að börn gætu tjáð sig og boðið öðrum að vera fullgildir pátttakendur. Á móti kom tilhneiging til að vera mjög eða frekar ósammála fullyrðingum um að börn væru of ung til að taka ábyrgð á að hafa alla með (52\%), að pau gætu ekki skapað eigin jafningjahópa (61\%) og pau væru ekki fær um að skilja sjónarmið barna með bakgrunn eða hæfni ólíka peirra eigin (59\%). Fram kom marktækur munur samkvæmt kí-kvaðrat-prófinu eftir menntun pátttakenda á afstöðu til pess hvort börn væru ófær um að skilja sjónarmið barna með ólíka hæfni og/eða bakgrunn, $X^{2}(20, \mathrm{~N}=141)=32,3, p=0,041$. Starfsfólk með framhaldsskólamenntun var líklegra til að vera sammála pví að börn væru ófær um pennan skilning en starfsfólk með leikskólakennaramenntun, BA-gráðu eða meistaragráðu.

Könnuð voru viðhorf leikskólakennara og leiðbeinenda til aðkomu og pátttöku foreldra í ákvörðunum eða samstarfi sem tengdist fullgildri pátttöku barnanna. Á Mynd 7 má sjá hversu sammála eða ósammála peir voru fullyrðingum sem tengdust pessu. 


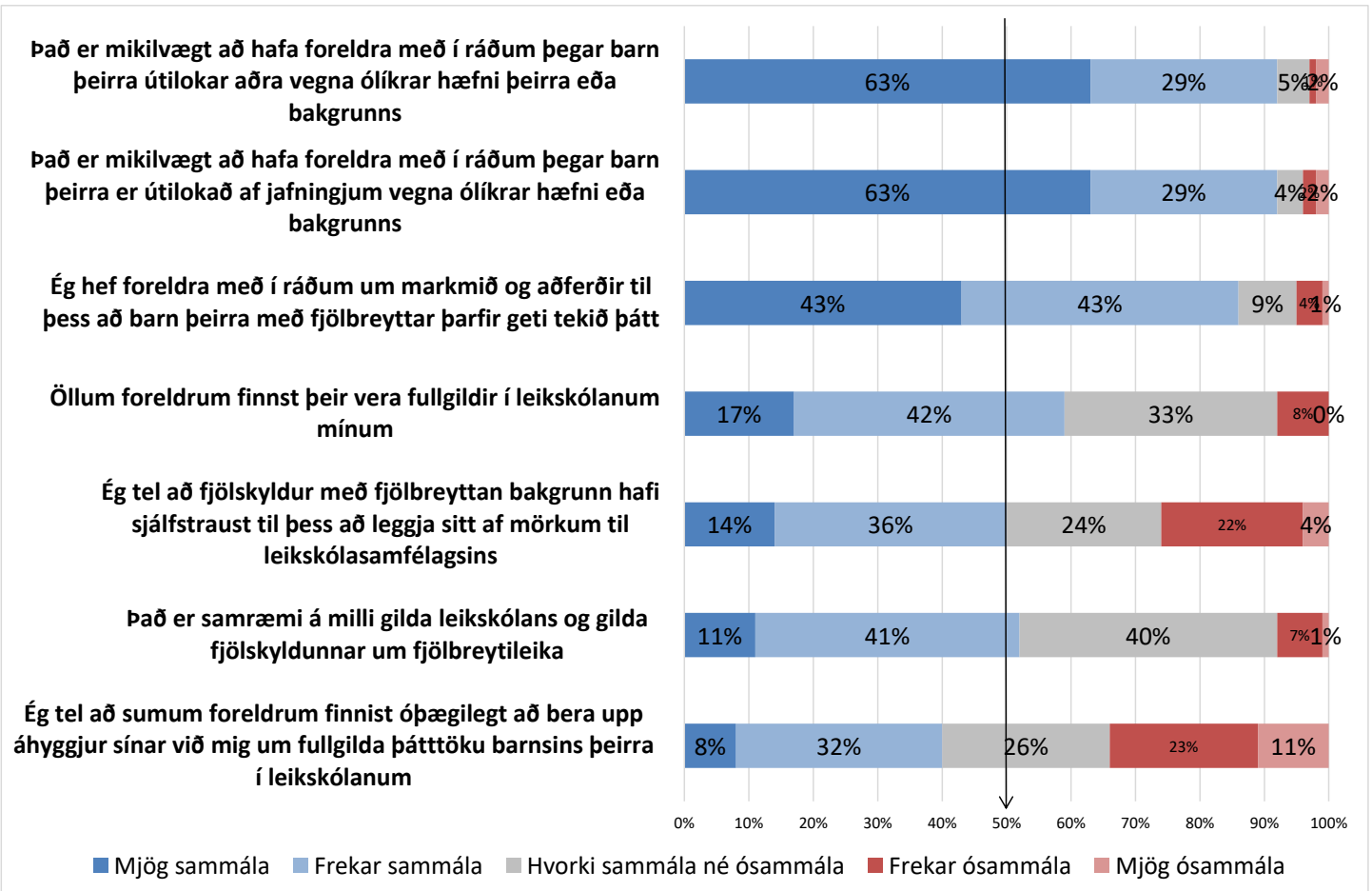

Mynd 7. Sýn á pátttöku foreldra í leikskólastarfinu.

Mikill meirihluti taldi mikilvægt að hafa foreldra með í ráðum pegar barn peirra útilokaði eða væri útilokað af jafningjum vegna ólíkrar hæfni eða bakgrunns. Yfir 60\% voru mjög sammála og um 30\% frekar sammála pví. Einnig töldu margir mikilvægt að hafa foreldra með í ráðum um markmið og aðferðir til pess að barn peirra með fjölbreyttar parfir gæti tekið pátt. Par voru $43 \%$ mjög sammála og önnur 43\% frekar sammála. Skiptar skoðanir voru um hvort foreldrum pætti ópægilegt að viðra áhyggjur sínar af fullgildri pátttöku barns. Pannig voru 40\% frekar eða mjög sammála pessu en 34\% mjög eða frekar ósammála. Fleiri voru peirrar skoðunar að fjölskyldur með fjölbreyttan bakgrunn hefðu sjálfstraust til að leggja sitt af mörkun til leikskólasamfélagsins, eða 50\%, en 26\% voru mjög eða frekar ósammála pví. Ekki reyndist vera munur eftir menntun eða starfsaldri á mati á pátttöku foreldra í leikskólastarfi pegar horft væri til fullgildrar pátttöku.

\section{Umræða}

Litið hefur verið á fullgildi sem veigamikinn pátt í nútímaleikskólamenntun og leikskóla sem mikilvægan vettvang fyrir félagslega pátttöku (Dahlberg og Moss, 2005). Í rannsókninni var leitast við að kanna starfshætti og sýn leikskólakennara og leiðbeinenda á fullgildi í leikskólastarfi. Jafnframt var reynt að öðlast skilning á sýn peirra á valdastöðu barna með fjölbreyttan tungumálaog menningarbakgrunn og hvernig peir sjá hlutverk sitt í að styðja börn og fjölskyldur til fullgildrar pátttöku. Gagna var aflað með spurningakönnun sem 143 starfsmenn leikskóla víðs vegar um landið svöruðu.

Kennarar gegna lykilhlutverki í að skapa skilyrði fyrir fullgildi í skólum. Рað hvernig litið er á og unnið er með fullgildi í leikskólastarfi veltur að verulegu leyti á gildum og gildismati starfsfólksins (Puroila o.fl., 2021; Yuval-Davis, 2006, 2011). Niðurstöður rannsóknarinnar sýndu að flestir pátttakendur stefndu að pví að öll börnin væru fullgildir pátttakendur í barnahópnum og að öll börn væru viðurkennd „eins og pau eru“, enda eru pau viðhorf í samræmi við stefnumótun stjórnvalda um skóla fyrir öll börn og til pess ætlast að kennarar beri virðingu fyrir börnum og fjölskyldum með ólíkan bakgrunn og ólík gildi (Purdue o.fl., 2009). Rannsóknir hafa pó sýnt að jákvæð viðhorf til fjölmenningarlegra starfshátta og fullgildrar pátttöku barna er oft meira í orði en á borði og að 
kennarar svari í samræmi við ríkjandi hugmyndir um pað sem er rétt (Jóhanna Einarsdóttir og Sara M. Ólafsdóttir, 2020b; Phillips, 2010).

Nokkur munur var á viðhorfum og gildum leikskólakennara og leiðbeinenda, einkum hvað varðar trú á hæfni barna og aðferðir til að stuðla að fullgildi. Einnig kom fram nokkur munur eftir menntun og starfsaldri.

Kennarar skapa skilyrði fyrir fullgildi, ekki eingöngu fyrir börnin heldur einnig foreldrana. Pað er pví ánægjulegt að flestir pátttakendur sögðust kjósa að hafa foreldra með í ráðum og vildu að peir tækju sem mestan pátt í starfinu. Petta er í samræmi við áherslur í aðalnámskrá leikskóla (Mennta- og menningarmálaráðuneytið, 2012). Par kemur fram að líðan barns sé samtvinnuð velferð fjölskyldu pess og litið er á sjónarmið foreldra og framlag peirra til leikskólastarfs sem mikilvægan lið í velferð og vellíðan barna. Í svörum starfffólksins mátti hins vegar greina óvissu um hvort foreldrar teldu sig geta leitað til starfsfólks ef peir hefðu áhyggjur af fullgildri pátttöku barna sinna. Nokkrum hluta starfsfólks pótti ekki heldur ljóst að foreldrar með annan menningarbakgrunn hefðu sjálfstraust til að taka pátt í starfi leikskólans. Petta gefur til kynna að svigrúm sé til að huga betur að samstarfi við foreldra og börn með erlendan bakgrunn.

Í svörum pátttakenda má greina sjónarmið peirra um getu oghæfni barna til að hafa áhrifáleikskólastarf og málefni sem pau varða. Starfsfólk með leikskólakennaramenntun og/eða meistaragráðu var líklegt til að hafa meiri trú á hæfni barna en peir sem höfðu minni menntun. Tillett og Wong (2018) komust að sambærilegri niðurstöðu. Í rannsókn peirra með áströlskum leikskólakennurum kom fram að peir sem höfðu meiri menntun og höfðu nýlega lokið námi höfðu dýpri skilning á fullgildi. Meirihluti leikskólakennara og leiðbeinenda, í peirri rannsókn sem hér er til umfjöllunar, hafði trú á hæfni leikskólabarna til að tjá sig og bjóða öðrum börnum að taka pátt og vera með. Jafnframt taldi meirihluti peirra að börn gætu stuðlað að fullgildi með sameiginlegum reglum. Peir sem lokið höfðu leikskólakennaramenntun, BA-gráðu og/eða meistaragráðu höfðu pó meiri trú á hæfni barna en starfsfólk sem hafði eingöngu framhaldsskólamenntun.

Pegar pátttakendur voru beðnir að velja á milli pess hvort peir legðu áherslu á að börn lærðu fullgildi í gegnum samskipti og leik með öðrum eða með pví að vera sjálfir fyrirmynd barnanna taldi meirihlutinn að börn lærðu best fullgildi í gegnum samskipti og leik og pau fyndu lausnir í jafningjahópnum á vanda sem sneri að fullgildi. Heldur hærra hlutfall peirra sem höfðu meistaragráðu hallaðist að pví að börn lærðu um fullgildi í gegnum samskipti og leik. Jafnframt voru peir sem lögðu áherslu á mikilvægi samskipta og leiks til að stuðla að fullgildi líklegri til að finnast börn fær um að skilja sjónarmið barna með ólíka hæfni eða bakgrunn. Pessar niðurstöður eru í samræmi við stefnumótun stjórnvalda sem birtist í aðalnámskrá leikskóla, par sem áhersla er lögð á hæfni barna, pátttöku peirra í ákvarðanatöku, samskipti, lýðræði og nám í gegnum leik (Jóhanna Einarsdóttir, 2017; Mennta- og menningarmálaráðuneytið, 2012). Рað kemur pví ekki á óvart að leikskólakennarar hafi frekar en annað starfsfólk tileinkað sér jákvæð viðhorf til hæfni barna og áherslu á nám í gegnum leik, enda hefur verið bent á að fullgildi endurspegli pólitíska sýn (Tillett og Wong, 2018), sé háð félagslegu samhengi og tengist hlutverki leikskólans í samfélaginu (May, 2013; Press o.fl., 2018).

Pegar pátttakendur voru beðnir að velja á milli pess hvort peir legðu áherslu á parfir einstakra barna eða parfir alls barnahópsins valdi meirihluti áherslu á parfir einstaklingsins og par voru leikskólakennarar í meirihluta. Pessar niðurstöður eru í samræmi við rannsóknir annars staðar á Norðurlöndum par sem komið hefur í ljós ákveðin togstreita milli áherslu á einstaklinginn annars vegar og hópinn hins vegar. Leikskólakennarar leggja pannig annars vegar áherslu á rétt sérhvers barns til að leika sér án pess að bjóða öðrum að vera með og hins vegar á félagslega pætti, svo sem félagslegan leik og sameiginlega iðju (Juutinen, 2018; Juutinen o.fl., 2018).

Af svörum við spurningum sem sneru að valdastöðu barna með fjölbreyttan tungumála- og menningarbakgrunn má ráða að starfsfólk komi helst auga á að börn verði fyrir útilokun af hálfu annarra barna ef pau hafa ekki tök á íslensku. Petta birtist einnig í svörum peirra um að börn með annað móðurmál en íslensku geti átt í erfiðleikum í samskiptum við jafningja. Yuval-Davis talar um 
pólitískt fullgildi sem snýst um hvað pað pýðir að vera pátttakandi og viðurkenndur í samfélagi og um pau landamæri sem aðgreina fólk og greina að „okkur“ og „pau“ (Yuval-Davis, 2006, 2011). Álykta má að starfsfólkið sem tók pátt í rannsókninni hafi skynjað pessi landamæri innan leikskólans par sem börn með annað móðurmál en íslensku voru flokkuð í sérstakan hóp (Puroila o.fl., í prentun).

Rannsóknir í leikskólum sýna að kunnátta og hæfni í tungumáli nýja landsins er einn fyrirferðarmesti pátturinn pegar rætt er um hindranir sem börn af erlendum uppruna mæta í skólastarfinu og í samskiptum við jafningja. Pess vegna ætti ekki að koma á óvart að pátttakendur í pessari rannsókn nefni helst útilokun í tengslum við íslenskukunnáttu. Petta undirstrikar mikilvægi pess að leggja áherslu á tungumálanám. Tungumálið er pó ekki eini pátturinn sem getur valdið jaðarsetningu barna með erlendan bakgrunn í leik og starfi í leikskólanum, fleira kemur til. Rannsóknir sýna að menningarmunur getur valdið pví að börn fá ekki að vera með í leik með öðrum börnum (Kernan, 2010; Sadownik, 2018). Kalkman og Clark (2017) komust t.d. að pví í rannsókn sinni að börn með erlendan bakgrunn í norskum leikskólum höfðu ekki pá menningarbundnu pekkingu sem purfti til að taka pátt í leik með félögum sínum í leikskólanum. Niðurstöður rannsóknarinnar sem hér er greint frá eru pví umhugsunarverðar vegna pess að pátttakendur komu hvorki auga á menningu né trú sem mögulegar ástæður útilokunar, og er pað atriði sem mætti skoða betur í rannsóknum hér á landi.

Í svörum starfsfólksins birtust bæði nokkrar áhyggjur af stöðu barna með annan tungumála- og menningarbakgrunn og vilji og áhugi á að stuðla að fullgildri pátttöku peirra í jafningjahópum. Petta birtist til dæmis í tengslum pess að öll börn séu fullgildir pátttakendur í barnahópnum og að líta svo á að börn með annað móðurmál en íslensku eigi í erfiðleikum með að taka pátt í samskiptum við önnur börn. Til að auka fullgilda pátttöku allra barna í leikskólastarfinu lagði stór hluti starfsfólks áherslu á að börn öðluðust skilning á fjölbreytileika og á umræðu barnanna um eigin tilfinningar og annarra um fjölbreytileika. Líklegt má telja að í pessu efni hafi starfsfólkið haft pau börn í huga sem standa höllum fæti vegna íslenskukunnáttu enda fundust tengsl milli áherslna á að auka skilning á fjölbreytileika og pess að telja börn með annað móðurmál en íslensku eiga erfitt með að taka pátt í samskiptum við jafningja.

Pað fór saman í huga starfsfólksins í rannsókninni að mikilvægt væri að börnin eignuðust vini í leikskólanum og treysta mætti á hæfni og virkni barna við að stuðla að pátttöku og fullgildi allra barna. Kennarar eru í lykilaðstöðu til að styðja vináttu ólíkra barna og aðstoða pau við að próa vináttutengsl. Með pví að skapa aðstæður og sameiginlega reynslu geta kennarar stuðlað að fullgildi barna með fjölbreyttan menningar- og tungumálabakgrunn (Wang o.fl., 2019; Zachrisen, 2018). Einnig hefur verið bent á mikilvægi pess að kennarar séu meðvitaðir um sjónarmið barna og hafi vald á kennsluaðferðum sem vinna gegn staðalímyndum og fordómum (Nutbrown og Clough, 2009). Pau markmið starfsfólksins í rannsókninni að auka skilning á fjölbreytileika og ræða tilfinningar sem tengjast honum eru mikilvægar leiðir til að styðja fullgildi allra barna.

\section{Niðurlag}

Leikskólastarf par sem byggt er á styrkleikum og reynslu barna ásamt samstarfi við fjölskyldur peirra getur skipt sköpum við að tryggja jafnræði fyrir börn með erlendan bakgrunn (UNESCO, 2019). Niðurstöður rannsóknarinnar undirstrika mikilvægi gildismats starfsfólks og sjónarmiða pess pegar stuðla á að virkri pátttöku allra barna í leikskólastarfinu, ekki síst barna af erlendum uppruna. Par má nefna áherslu á vináttu, samskipti og leik og trú á hæfni barna til að leysa mál sem tengjast fjölbreyttum bakgrunni peirra. Rannsóknin gefur einnig til kynna að huga megi betur að samstarfi við fjölskyldur barna með fjölbreyttan bakgrunn og að starfsfólk hafi áhyggjur af pessum hópi barna sem taka ber alvarlega.

Rannsóknin veitir gagnlega innsýn í gildismat starfsfólks og sýn pess á börn og starf sem stuðlar að fullgildi allra barna. Takmarkanir rannsóknarinnar eru fremur lítið úrtak og gæti stærra úrtak sem byggt væri á handahófsaðferð gefið skýrari niðurstöður. Pá vöknuðu spurningar sem frekari 
rannsóknir gætu varpað ljósi á, til dæmis um hvernig menntun starfsfólks undirbýr pað fyrir vinnu að fullgildri pátttöku og hvernig unnt væri að gera foreldra öruggari með að leita til starfsfólks með áhyggjur sínar. Pá er mikilvægt að kanna betur upplifun starfsfólks á hindrunum barna af erlendum uppruna í jafningjahópi.

\section{Preschool Educators' Values and Perspectives on Belonging in Diverse Groups of Children}

Preschool children's relationships with their peers and their educators are essential for their education and well-being. If these relationships are strong, children experience a feeling of belonging to their preschool community. This study is informed by the concept of 'belonging' (Yuval-Davis, 2006; Juutinen, 2018). It refers to participation and relationships and the feeling of belonging to a group of children in preschool. With increasing diversity in the preschool population, it is important to understand how preschool educators support children's belonging. The aim of the study is to shed light on educators' values and perspectives on children's belonging in preschool. The study also explored whether diverse views on children and belonging were mirrored in the educators' responses and how they saw the power positions of children with diverse language and cultural backgrounds.

The research questions are as follows:

1. Do the participants have different perspectives on children and belonging?

2. Which values are reflected by the educators' perspectives and practices on belonging?

3. How do the educators see their role in supporting children and families to foster belonging in preschool?

4. What are the educators' perspectives on the power positions of children with diverse language and cultural backgrounds?

Globalization and increased diversity have a formative influence on educators' practices. Icelandic society has evolved during a short period of time, from a homogeneous society to a diverse society. Every year the number of preschool children with diverse language and cultural backgrounds increases and thus, during a short period of time, preschools have become intercultural arenas. In 2009, 1,614 preschool children had a home language other than Icelandic; by 2019, this number increased to 2,713 children (Hagstofa Íslands, 2020a). Research has shown that children with foreign backgrounds are in danger of being left out of their peer group and, thus, the support of educators can be crucial for their belonging in the preschool community (Eyrún María Rúnarsdóttir \& Svava Rán Valgeirsdóttir, 2019; Jóhanna Einarsdóttir \& Sara M. Ólafsdóttir, 2020a, 2020b; Sadownik, 2018).

Data was gathered through an electronic survey which 143 preschool educators in Iceland answered. Approximately half of the respondents were preschool teachers and/or had a bachelor's degree, one fourth had completed a master's degree or a diploma following a bachelor's degree, and one fourth had high school diploma or other education. The findings indicate convergence in the views and values of the participants, especially regarding their perspectives on the competences of children and practices to support belonging in preschools. Responses varied according to education level and period of employment. However, most participants replied that their aim was for all children to be included in the group and for all children to be accepted "as they are." Most of the educators also felt that parents should be consulted and expressed their willingness to include parents in the preschool practices. This is consistent with the national curriculum guidelines for preschool emphasis (Mennta- og menningarmálaráðuneytið, 2012). 
In the educators' responses, their perspectives on children's competences and abilities to influence the preschool pedagogy were evident. Those who had preschool teacher education or master's degrees believed more strongly in children's competences and abilities to invite other children to participate than those with less education. When the participants were asked to choose between children learning belonging through play and interaction with other children or from them being role models for the children, those with a master's degree were more likely to believe that children learned through play and relationships with other children. They were also more likely to find children competent to understand perspectives of children who had different competences and backgrounds.

Concerning the power position of children, the educators mainly thought language could exclude children from their peer group and were concerned about the position of children with diverse language and cultural backgrounds. Few mentioned culture or religion, issues that previous research has shown to be important for children's belonging (Kalkman \& Clark, 2017; Kernan, 2010; Sadownik, 2018). The participants showed willingness to promote belonging among children with foreign backgrounds through understanding and discussion about diversity and emphasis on peer friendships.

Key words: Belonging, educators' values, children with diverse language and cultural backgrounds, preschool practices

\section{Um höfunda}

Jóhanna Einarsdóttir (joein@hi.is) er prófessor í menntunarfræðum ungra barna við Menntavísindasvið Háskóla Íslands. Hún er einnig heiðursdoktor við Háskólann í Oulu í Finnlandi. Hún hlaut viðurkenningu fyrir framlag sitt til rannsókna á menntun ungra barna frá University of Illinois árið 2018. Hún hefur stundað rannsóknir í leik- og grunnskólum um árabil og ritað fjölda fræðigreina og bóka um efnið. Sérsvið hennar eru rannsóknir með börnum, samfella í námi barna og starfendarannsóknir. Hún er pátttakandi í alpjóðlegum rannsóknarverkefnum, bæði sem rannsakandi og ráðgjafi. Jóhanna situr í stjórn European Early Childhood Education Research Association.

Eyrún María Rúnarsdóttir (emr@hi.is) er lektor í uppeldis- og menntunarfræði við Menntavísindasvið Háskóla Íslands. Rannsóknir hennar eru á sviði unglingarannsókna og beinast að unglingum af erlendum uppruna, líðan peirra, vinatengslum og félagslegum stuðningi frá vinum og foreldrum. Eyrún lauk BA-gráðu í uppeldis- og menntunarfræði árið 1996 og meistaragráðu í sömu grein árið 2002 frá Háskóla Íslands. Pá lauk hún doktorsgráðu frá Menntavísindasviði Háskóla Íslands árið 2019.

\section{About the authors}

Jóhanna Einarsdóttir (joein@hi.is) is a professor of education at the School of Education, University of Iceland. She holds an Honorary Doctorate from the University of Oulu in Finland and was awarded The Distinguished Alumni Achievement Award from University of Illinois in 2018. Professor Einarsdóttir has published and presented numerous papers and research results on early childhood education, educational transitions, and children's perspectives on their preschool education, to professional and community groups nationally as well as internationally. Jóhanna is on EECERA Board of Trustees.

Eyrún María Rúnarsdóttir (emr@hi.is) is an assistant professor of education studies at the School of Education, University of Iceland. Her research field is foreign-origin adolescents' well-being in relation to their sociodemographic background and social support from friends and family. Eyrún completed a bachelor's degree in education 
studies in 1996 and a master's degree in the same subject in 2002 from the University of Iceland. She completed her PhD degree from the School of Education in 2019.

\section{Athugasemdir}

Hugtakið fullgildi er nýyrði og er pýðing á enska orðinu belonging og vísar til peirrar tilfinningar að tilheyra hópi. Hugtakið er í pessari rannsókn notað til að varpa ljósi á sjónarmið starfsfólks leikskóla á félagsleg samskipti barna og pátttöku peirra í leikskólanum.

Rannsóknin er hluti af stærri rannsókn par sem fullgildi barna er rannsakað út frá sjónarhóli barna, foreldra og kennara.

Heildarrannsóknin var styrkt af:

Rannís, Educational Continuity: Supporting Positive Transition for Children from Diverse Backgrounds nr. 163325-052

NordForsk, Politics of belonging: Promoting Children's Inclusion in Educational Settings across Borders nr. 85644

Rannsóknarsjóði Háskóla Íslands

\section{Heimildir}

Antonsich, M. (2010). Searching for belonging - An analytical framework. Geography Compass, 4(6), 644-659. doi:10.1111/j.1749-8198.2009.00317.x

Arvola, O., Lastikka, A.-L. og Reunamo, J. (2017). Increasing immigrant children's participation in the Finnish early childhood education context. The European Journal of Social and Behavioural Sciences, 20(3), 2538-2548. doi: 10.15405/ejsbs.223

Cerna, L., Andersson, H., Bannon, M. og Borgonovi, F. (2019). Strength through diversity's spotlight report for Sweden. Sótt af https://www.oecd-ilibrary.org/docserver/059ce467-en.pdf?expires=1605795809\&id=i $\mathrm{d} \&$ accname $=$ guest\&checksum $=9$ FD5432A1B8E419CDEB88BC4101B1DA5

Dahlberg, G. og Moss, P. (2005). Ethics and politics in early childhood education. London: RoutledgeFalmer.

Evans, J. E. og Mathur, A. (2018). The value of online surveys: A look back and a look ahead. Internet Research, 28(4), 854-887. doi:10.1108/IntR-03-2018-0089

Evrópuráðið. (2019). Council recommendations of 22 May 2019. On high-quality early childhood education and care system. Official Journal of the European Union. Sótt af https://eur-lex.europa.eu/legal-content/EN/ TXT/PDF/?uri=CELEX:32019H0605(01)\&from=EN

Eyrún María Rúnarsdóttir og Svava Rán Valgeirsdóttir. (2019). „Peir leika saman og eru glaðir, pað er bara svo gott“: Félagsleg tengsl og vinátta leikskólabarna af erlendum uppruna. Sérrit Netlu 2019-Menntun barna i leikskóla og yngsta stigi grunnskóla. Sótt af http://netla.hi.is/serrit/2019/menntun_barna_leik_grunn/03.pdf

Hagstofa Íslands. (2020a). Börn í leikskólum með erlent móðurmál 1998-2019. Sótt af https://px.hagstofa.is/ pxis/pxweb/is/Samfelag/Samfelag_skolamal_1_leikskolastig_0_lsNemendur/SKO01103.px

Hagstofa Íslands. (2020b). Starfsfólk í leikskólum eftir menntun 1998-2019. Sótt af https://px.hagstofa.is/ pxis/pxweb/is/Samfelag/Samfelag_skolamal_1_leikskolastig_1_lsStarfsfolk/SKO01303.px

Jóhanna Einarsdóttir. (2017). Lýðræði, umhyggja og hæfni í Aðalnámskrá leikskóla. Sérrit Netlu 2017-Innsýn i leikskólastarf. Sótt af https://netla.hi.is/serrit/2017/innsyn_leikskolastarf/005.pdf 
Jóhanna Einarsdóttir og Sara M. Ólafsdóttir. (2020a). Children’s perspectives on belonging in Icelandic preschools. Í J. Murray, B. B. Swadener og K. Smith (ritstjóri), The Routledge international handbook of young children's rights (bls. 434-446). London/New York: Routledge.

Jóhanna Einarsdóttir og Sara M. Ólafsdóttir. (2020b). Fullgildi í leikskóla: Sjónarmið barna og starfsfólks. Timarit um uppeldi og menntun, 29(2), 113-131. doi:10.24270/tuuom.2020.29.6

Juutinen, J. (2018). Inside or outside? Small stories about the politics of belonging in preschools. Oulu: University of Oulu.

Juutinen, J., Puroila, A.-M. og Johansson, E. (2018). “There is no room for you!” The politics of belonging in children's play situations. Í E. Johansson, A. Emilson og A.-M. Puroila (ritstjórar), Values education in early childhood settings: Concepts, approaches and practices (bls. 249-264). Cham: Springer.

Kalkman, K. og Clark, A. (2017). Here we like playing princesses - newcomer migrant children's transitions within day care: Exploring role play as an indication of suitability and home and belonging. European Early Childhood Education Research Journal, 25(2), 292-304. doi: 10.1080/1350293X.2017.1288020

Kernan, M. (2010). Space and place as a source of belonging and participation in urban environments: Considering the role of early childhood education and care settings. European Early Childhood Education Research Journal, 18(2), 199-213. doi:10.1080/13502931003784420

Kultti, A., Pramling, N. og Pramling Samuelsson, I. (2017). Young children's participation in a new language context: A synthesising analysis for a holistic perspective. Í A. C. Gunn og C. A. Hruska (ritstjórar), Interactions in early childhood education: Recent research and emergent concepts (bls. 55-68). Singapore: Springer.

May, V. (2013). Connecting self to society: Belonging in a changing world. New York: PalgraveMacmillan.

Mennta- og menningarmálaráðuneytið. (2012). Aðalnámskrá leikskóla 2011. Sótt af https://www.stjornarradid. is/gogn/rit-og-skyrslur/stakt-rit/2012/03/27/Adalnamskra-leikskola-2011/

Ministry of Education New Zealand. (2017). Te Whariki. Sótt af https://education.govt.nz/assets/Documents/ Early-Childhood/ELS-Te-Whariki-Early-Childhood-Curriculum-ENG-Web.pdf

Nutbrown, C. og Clough, P. (2009). Citizenship and inclusion in the early years: Understanding and responding to children's perspectives on 'belonging'. International Journal of Early Years Education, 17(3), 191-206. doi: $10.1080 / 09669760903424523$

OECD. (2019). TALIS. Providing quality early childhood education and care: Results from the Starting Strong Survey 2018. doi:10.1787/301005d1-en

Over, H. (2016). The origins of belonging: Social motivation in infants and young children. Philosophical Transactions of the Royal Society of London Series B - Biological Sciences, 371(1686), 1-8. doi:10.1098/rstb.2015.0072

Phillips, L. G. (2010). Social justice storytelling and young children's active citizenship. Discourse: Studies in the Cultural Politics of Education, 31(3), 363-376. doi:10.1080/01596301003786993

Press, F., Woodrow, C., Logan, H. og Mitchell, L. (2018). Can we belong in a neo-liberal world? Neo-liberalism in early childhood education and care policy in Australia and New Zealand. Contemporary Issues in Early Childhood, 19(4), 328-339. doi:10.1177/1463949118781909

Purdue, K., Gordon-Burns, D., Gunn, A., Madden, B. og Surtees, N. (2009). Supporting inclusion in early childhood settings: Some possibilities and problems for teacher education. International Journal of Inclusive Education, 13(8), 805-815. doi:10.1080/13603110802110743

Puroila, A.-M., Emilson, A., Pálmadóttir, H., Piskur, B. og Tofteland, B. (í prentun). Educators' interpretations of children's belonging across borders: Thinking and talking with an image.

Puroila, A.-M., Juutinen, J., Viljamaa, E., Kyrönlampi, T. og Takala, M. (2021). Children belonging in Finnish educational settings: An intersectional analysis. International Journal of Early Childhood. doi:10.1007/ s13158-021-00282-y

Sadownik, A. (2018). Belonging and participation at stake. Polish migrant children about (mis)recognition of their needs in Norwegian ECECs. European Early Childhood Education Research Journal, 26(6), 956-971. https://doi.org/10.1080/1350293X.2018.1533711

Stratigos, T., Bradley, B. og Sumsion, J. (2014). Infants, family day care and the politics of belonging. International Journal of Early Childhood, 46(2), 171-186. doi: 10.1007/s13158-014-0110-0 
Tillett, V. og Wong, S. (2018). An investigative case study into early childhood educators' understanding about 'belonging'. European Early Childhood Education Research Journal 26(1), 37-49. doi:10.1080/1350 293X.2018.1412016

UNESCO. (2019). Global education monitoring report. Migration, displacement and education: Building bridges, not walls. Sótt af https://en.unesco.org/gem-report/report/2019/migration

Wang, Y., Palonen, T., Hurme, T.-R. og Kinos, J. (2019). Do you want to play with me today? Friendship stability among preschool children. European Early Childhood Education Research Journal, 27(2), 170-184. doi: 10.1080/1350293X.2019.1579545

Yuval-Davis, N. (2006). Belonging and the politics of belonging. Patterns of Prejudice, 4(3), 197-214.

Yuval-Davis, N. (2011). The politics of belonging: Intersectional contestations. London: Sage.

Zachrisen, B. (2018). Play in an ethnically diverse preschool: Conditions for belonging. Í E. Johansson og Jóhanna Einarsdóttir (ritstjórar), Values in Early Childhood Education: Citizenship for Tomorrow (bls. 132-146). Oxon: Routledge.

Jóhanna Einarsdóttir og Eyrún María Rúnarsdóttir. (2021).

Gildismat og sýn starfsfólks leikskóla á fullgildi í fjölbreyttum barnahópi.

Netla - Veftímarit um uppeldi og menntun. Menntavísindasvið Háskóla Íslands.

Sótt af https://netla.hi.is/greinar/2021/alm/02.pdf

DOI: https://doi.org/10.24270/netla.2021.2 